\title{
Role of Adhesiolysis in the Management of Chronic Spinal Pain: A Systematic Review of Effectiveness and Complications
}

\author{
Pradeep Chopra, MD, Howard S. Smith, MD, PhD, Timothy R. Deer, MD, and Richard C. Bowman, MD
}

Background: Percutaneous epidural adhesiolysis and spinal endoscopic adhesiolysis are interventional pain management techniques that play an active role in managing chronic intractable low back pain. There have not been any systematic reviews performed on this subject.

Objective: To evaluate the effect of percutaneous adhesiolysis and spinal endoscopic adhesiolysis in managing chronic low back and lower extremity pain.

Study Design: A systematic review utilizing the methodologic quality criteria of the Cochrane Musculoskeletal Review Group for randomized trials and the criteria established by the Agency for Healthcare Research and Quality (AHRQ) for evaluation of randomized and non-randomized trials.

Methods: Search identified the relevant literature, through searches of MEDLINE and EMBASE (January 1966 to November 2004), BioMed Central and Cochrane Review database. Manual searches of bibliographies of known primary and review articles, and ab-

Chronic low back pain has a prevalence ranging from $35 \%$ to $75 \%$ at 12 months after the initial attack (1-6). Kuslich et al (7) were able to identify different tissue such as intervertebral discs, nerve root dura, facet joints, ligaments and muscles that were potentially capable of transmitting pain. Post lumbar laminectomy syndrome, vascular compromise, spinal stenosis and inflammatory response have also been implicated

From Brown Medical School, Providence, RI, and Boston University School of Medicine, Boston, MA, Albany Medical College, Albany, NY, and The Center for Pain Relief, Charleston, WV.

Address Correspondence: Pradeep Chopra, MD, 102 Smithfield Ave, Pawtucket, RI 02860.

Disclaimer: Nothing of monetary value was received in the preparation of this manuscript. Conflict of Interest: None

Acknowledgement:

Manuscript received on 12/16/2004

Revision submitted on 01/07/2005

Accepted for publication on 01/07/2005 stracts from scientific meetings within the last 2 years, in English language. Randomized and non-randomized studies were included in the review based on the criteria established.

Three reviewers independently assessed the trials for the quality of their methods. Percutaneous adhesiolysis and endoscopic adhesiolysis were analyzed separately.

Outcome Measures: Primary outcome measure was significant pain relief $(50 \%$ or greater). Other outcome measures were functional improvement, improvement of psychological status, and return to work. Short-term relief was defined as less than 3 months, and long-term relief was defined as 3 months or longer.

Results: There was strong evidence to indicate effectiveness of percutaneous epidural adhesiolysis with administration of epidural steroids for short term and long term in chronic, refractory low back pain and radicular pain. There was moderate evidence of ef- fectiveness of addition of hypertonic saline. The evidence of effectiveness of hyaluronidase was negative.

There was strong evidence to indicate effectiveness of spinal endoscopic adhesiolysis and epidural steroid administration for short-term improvement, and moderate evidence for long-term improvement in managing chronic, refractory, low back and lower extremity pain.

Conclusion: The evidence of effectiveness of percutaneous adhesiolysis with administration of hypertonic sodium chloride administration, and spinal endoscopic adhesiolysis with epidural steroid administration in managing chronic, refractory low back and lower extremity pain of post lumbar laminectomy syndrome or epidural fibrosis was moderate to strong.

Keywords: Spinal pain, chronic low back pain, percutaneous adhesiolysis, spinal endoscopic adhesiolysis, spinal stenosis, post lumbar laminectomy syndrome, epidural fibrosis. in chronic low back pain. Post operative epidural fibrosis may contribute from 5\% to $60 \%$ of poor surgical outcome following decompressive surgery $(1,8-12)$. The prevalence of pain following surgery for the lumbar spine, also known as post lumbar laminectomy syndrome is estimated in approximately $5 \%$ to $40 \%$ of patients after surgical intervention (13-16). Ross et al (10) and other authors have reported a correlation between peridural scarring and radicular pain $(11,17)$, and poor clinical outcomes $(13,14)$, while others have questioned the role of epidural fibrosis as a cause of chronic pain $(15,16,18)$.

Hematoma formation in the epidural space during the post operative period is invaded by dense fibrous tissue from the periosteum and the deep surface of the paravertebral musculature $(19,20)$. Fibrous tissue in the epidural space may adhere to the dura mater and nerve roots; this causes a mechanical tethering of the nerve roots or the dura. This mechanical tethering may contribute to chronic low back pain and lower extremity pain following lumbar laminectomy in significant subset of patients. LaRocca and McNab (19) have demonstrated the presence of fibrous connective tissue causing epidural fibrosis into a postoperative hematoma. Fibrosis in the spinal canal may also develop without any surgical intervention as in infection, hematoma, annular tear or intrathecal contrast media (20-22). McCarron et al (20) reported an inflammatory reaction in spinal cord sections taken from dogs sacrificed after an initial injection of homogenized nucleus pulposus. Cooper et al (21) were able to identify periradicular fibrosis and vascular abnormalities occurring with herniated intervertebral discs. Parke and Watanabe (22) demonstrated epidural adhesions in 
$40 \%$ of cadavers with lumbar disc herniation at L4-L5 level, 36\% at L5-S1 level and in $16 \%$ at L3-L4 level. Perineural fibrosis can interfere with cerebrospinal fluid mediated nutrition, which can render the nerve roots to be hyperesthetic and hypersensitive to compression $(11,23,24)$. Ross et al (10), in a study of the relationship between epidural fibrosis and radicular pain, showed that subjects with extensive scarring were 3.2 times more likely to experience radicular pain, as evaluated by magnetic resonance imaging after lumbar laminectomy.

Traditionally, fluoroscopically di-

Table 1. Domains and elements for randomized controlled trials

\begin{tabular}{|c|c|}
\hline Domain $^{\#}$ & Elements ${ }^{*}$ \\
\hline Study Question & - Clearly focused and appropriate question \\
\hline Study Population & $\begin{array}{l}\text { - Description of study population } \\
\text { - Specific inclusion and exclusion criteria } \\
\text { - Sample size justification }\end{array}$ \\
\hline Randomization & $\begin{array}{l}\text { - Adequate approach to sequence generation } \\
\text { - Adequate concealment method used } \\
\text { - Similarity of groups at baseline }\end{array}$ \\
\hline Blinding & $\begin{array}{l}\text { - Double-blinding (e.g., of investigators, caregivers, subjects, } \\
\text { assessors, and other key study personnel as appropriate) to } \\
\text { treatment allocation }\end{array}$ \\
\hline Interventions & $\begin{array}{l}\text { - Intervention(s) clearly detailed for all study groups (e.g., } \\
\text { dose, route, timing for drugs, and details sufficient } \\
\text { for assessment and reproducibility for other types of } \\
\text { interventions) } \\
\text { - Compliance with intervention } \\
\text { - Equal treatment of groups except for intervention }\end{array}$ \\
\hline Outcomes & $\begin{array}{l}\text { - Primary and secondary outcome measures specified } \\
\text { - Assessment method standard, valid, and reliable }\end{array}$ \\
\hline Statistical Analysis & $\begin{array}{l}\text { - Appropriate analytic techniques that address study } \\
\text { withdrawals, loss to follow-up, missing data, and intention } \\
\text { to treat } \\
\text { - Power calculation } \\
\text { - Assessment of confounding } \\
\text { - Assessment of heterogeneity, if applicable }\end{array}$ \\
\hline Results & $\begin{array}{l}\text { - Measure of effect for outcomes and appropriate measure of } \\
\text { precision } \\
\text { - Proportion of eligible subjects recruited into study and } \\
\text { followed up at each assessment }\end{array}$ \\
\hline Discussion & $\begin{array}{l}\text { - Conclusions supported by results with possible biases and } \\
\text { limitations taken into consideration }\end{array}$ \\
\hline Funding or Sponsorship & - Type and sources of support for study \\
\hline
\end{tabular}

${ }^{*}$ Key domains are in italics

*Elements appearing in italics are those with an empirical basis. Elements appearing in bold are those considered essential to give a system a Yes rating for the domain.

$\dagger$ Domain for which a Yes rating required that a majority of elements be considered.

Adapted from ref 31 rected lumbar epidural corticosteroid injections have been used in interventional pain management to treat chronic low back pain and lumbar radiculopathy. Philips and Cunningham in 2002 (25) in describing the role of decompressive surgery in managing chronic pain of spinal origin after lumbar surgery, noted that no forms of surgical treatment or adhesion lysis procedure for this diagnosis has proven to be safe and effective.

Percutaneous and endoscopic adhesiolysis have been employed in interventional pain management in management of chronic, refractory low back and low-

er extremity pain. The purpose of percutaneous epidural lysis of adhesions is to eliminate deleterious effects of scar formation, which can physically prevent direct application of drugs (steroids, hypertonic saline, hyaluronidase) to nerves or other tissues to treat chronic back and extremity pain. The goal of percutaneous lysis of epidural adhesions is to assure delivery of high concentrations of injected drugs to the target areas $(1,26-30)$. Epidural lysis of adhesions and direct deposition of corticosteroids in the spinal canal are also achieved with a 3-dimensional view provided by epiduroscopy or spinal endoscopy $(1,26-30)$.

This systematic review was undertaken to determine the evidence pertaining to effectiveness of percutaneous and endoscopic adhesiolysis in the management of chronic low back and lower extremity pain. We sought to answer the following questions:

In managing chronic low back and lower extremity pain -

1. Is percutaneous adhesiolysis an effective treatment?

2. Is percutaneous adhesiolysis superior to epidural steroid injections?

3. Does the addition of hypertonic sodium chloride solution improve outcomes?

4. Does the addition of hyaluronidase improve outcomes?

5. Is percutaneous adhesiolysis a safe procedure?

6. Is spinal endoscopic adhesiolysis an effective treatment?

7. Is spinal endoscopic adhesiolysis superior to percutaneous adhesiolysis?

8. Is spinal endoscopic adhesiolysis a safe procedure?

\section{Methods}

\section{Literature Search}

The strategy utilized for evidence synthesis was comprehensive and included a detailed literature search of EMBASE, MEDLINE (Jan 1966 - Nov 2004), Bio Med Central and Cochrane Reviews. All systematic and narrative reviews; all relevant and published peer-reviewed indexed and non-indexed journals; cross-references to the reviews; scientific meeting proceedings, scientific newsletters; various published trials. The search strategy consisted of interventional techniques, lysis of epidural adhesions, percutaneous adhesiolysis, endoscopic adhesiolysis, with 
emphasis on chronic pain, low back pain and lumbar radicular pain.

\section{Selection Criteria}

All randomized clinical trials, observational studies, and abstracts presented in the last 2 years published in English language were considered for inclusion. The population of interest was patients suffering with chronic lumbar and sacral spinal pain with or without lower extremity pain for at least 6 months.

\section{Outcome Measures}

The primary outcome measure was percentage of patients with pain relief. The secondary outcome measures were

Table 2. Domains and elements for observational studies

\begin{tabular}{|c|c|}
\hline Domain $^{\#}$ & Elements $^{\star}$ \\
\hline Study Question & - Question clearly specified and appropriate \\
\hline Search Strategy & $\begin{array}{l}\text { - Sufficiently comprehensive and rigorous with attention to } \\
\text { possible publication biases } \\
\text { - Search restrictions justified (e.g., language or country of } \\
\text { origin) } \\
\text { - Documentation of search terms and databases used } \\
\text { - Sufficiently detailed to reproduce study }\end{array}$ \\
\hline $\begin{array}{l}\text { Inclusion and Exclusion } \\
\text { Criteria }\end{array}$ & $\begin{array}{l}\text { - Selection methods specified and appropriate, with a priori } \\
\text { criteria specified if possible }\end{array}$ \\
\hline Interventions & - Intervention(s) clearly detailed for all study groups \\
\hline Outcomes & - All potentially important harms and benefits considered \\
\hline Data Extraction $\dagger$ & $\begin{array}{l}\text { - Rigor and consistency of process } \\
\text { - Number and types of reviews } \\
\text { - Blinding of reviewers } \\
\text { - Measure of agreement or reproducibility } \\
\text { - Extraction of clearly defined interventions/exposures and } \\
\text { outcomes for all relevant subjects and subgroups }\end{array}$ \\
\hline Study Quality and Validity & $\begin{array}{l}\text { - Assessment method specified and appropriate } \\
\text { - Method of incorporation specified and appropriate }\end{array}$ \\
\hline $\begin{array}{l}\text { Data Synthesis and } \\
\text { Analysis }\end{array}$ & $\begin{array}{l}\text { - Appropriate use of qualitative and/or quantitative } \\
\text { synthesis, with consideration of the robustness of results } \\
\text { and heterogeneity issues } \\
\text { - Presentation of key primary study elements sufficient for } \\
\text { critical appraisal and replication }\end{array}$ \\
\hline Results & $\begin{array}{l}\text { - Narrative summary and/or quantitative summary statistic } \\
\text { and measure of precision, as appropriate }\end{array}$ \\
\hline Discussion & $\begin{array}{l}\text { - Conclusions supported by results with possible biases and } \\
\text { limitations taken into consideration }\end{array}$ \\
\hline Funding or Sponsorship & - Type and sources of support for study \\
\hline
\end{tabular}

${ }^{\#}$ Key domains are in italics

${ }^{\star}$ Elements appearing in italics are those with an empirical basis. Elements appearing in bold are those considered essential to give a system a Yes rating for the domain.

$\dagger$ Domain for which a Yes rating required that a majority of elements be considered.

Adapted from ref 31 functional or psychological improvement, return to work, and complications. Pain relief was evaluated on a short-term (less than 3 months) and long-term (3 months or longer) basis.

\section{Review Methods}

The quality of individual articles was evaluated using the criteria from the Agency for Healthcare Research and Quality (AHRQ) publication (31). Important domains and elements for randomized and non-randomized trials are shown in Tables 1 and 2. For evaluation of randomized trials, criteria described by Cochrane Review Group for musculoskeletal disorders (32) was also utilized
(Table 3).

A study was regarded as relevant if at least one of the questions sought to be answered, and at least one of the outcome measures concerned pain intensity, overall improvement, or functional status were evaluated. A study was considered for inclusion only if the methodological score was $50 \%$ or more. Randomized trials not meeting the $50 \%$ criteria were also considered for inclusion as observational studies.

\section{Inclusion and Exclusion Criteria}

Only studies that met an inclusion algorithmic criterion (Figure 1) and criteria as listed in Table 4 were included (33).

\section{Prior Treatment Criteria}

The patients should have been tried either one or multiples of non-interventional techniques or should have undergone surgical intervention. Non-interventional techniques must have included exercises, physical therapy with activity improvement, chiropractic management, and drug therapy with non-steroidal antiinflammatory agents.

For percutaneous adhesiolysis, prior treatments included fluoroscopically directed epidural steroids.

For endoscopic adhesiolysis, prior treatments included fluoroscopically directed epidural steroids and percutaneous adhesiolysis.

\section{Data Extraction}

Study evaluation, inclusion and exclusion algorithmic approach is shown in Figure 1 and Table 4. Methodologic quality assessment was performed as described in "review methods" section.

\section{Analysis of Evidence}

A qualitative analysis was conducted, using five levels of evidence for effectiveness of adhesiolysis as illustrated in Table 5. Duration of pain relief was considered for both short-term and long-term. Short-term relief was considered as less than 3 months and long-term was considered as 3 months or longer. A study was judged to be positive if the authors concluded that the adhesiolysis was more effective than the reference treatment in randomized trials or simply concluded that it was effective in other studies. All other conclusions were considered negative. If, in the opinion of reviewers, there was conflict with the conclusion, the con- 
Table 3. Methodologic quality criteria list (key items of internal validity) of Cochrane Musculoskeletal Review Group

\begin{tabular}{|c|c|c|c|}
\hline \multicolumn{4}{|l|}{ Patient selection } \\
\hline \multicolumn{4}{|l|}{ 1. Treatment allocation } \\
\hline Was the method of randomization described and adequate? & Yes & No & Don't know \\
\hline Was the treatment allocation concealed? & Yes & No & Don't know \\
\hline 2. Were the groups similar at baseline regarding the most important prognostic indicators? & Yes & No & Don't know \\
\hline \multicolumn{4}{|l|}{ Intervention } \\
\hline 3. Was the care provider blinded? & Yes & No & Don't know \\
\hline 4. Was controlled for co-interventions which could explain the results? & Yes & No & Don't know \\
\hline 5. Was the compliance rate (in each group) unlikely to cause bias? & Yes & No & Don't know \\
\hline 6. Was the patient blinded? & Yes & No & Don't know \\
\hline \multicolumn{4}{|l|}{ Outcome measurement } \\
\hline 7. Was the outcome assessor blinded? & Yes & No & Don't know \\
\hline 8. Was at least one of the primary outcome measures applied? & Yes & No & Don't know \\
\hline 9. Was the withdrawal/drop-out rate unlikely to cause bias? & Yes & No & Don't know \\
\hline \multicolumn{4}{|l|}{ Statistics } \\
\hline 10. Did the analysis include an intention-to-treat analysis? & Yes & No & Don't know \\
\hline
\end{tabular}

Adapted from ref 32

clusions were changed with appropriate explanation.

RESULTS

Percutaneous Adhesiolysis

Table 4. Inclusion/exclusion criteria

1. Are the patients described in sufficient detail to allow you to decide whether they are comparable to those that are seen in clinical practices of interventional pain management?

A) Setting - office, hospital, outpatient, inpatient

B) Physician - interventional pain physician, general physician, anesthesiologist, physiatrist, neurologist, rheumatologist, orthopedic surgeon, neurosurgeon, etc.

C) Patient characteristics - duration of pain

D) Non-interventional techniques or surgical intervention in the past

E) Exclusion criteria

F) Inclusion criteria

2. Is the intervention described well enough to enable you to provide the same for patients in interventional pain management settings?

A) Nature of intervention

B) Frequency of intervention

C) Duration of intervention

3. Were clinically relevant outcomes measured?
A) Proportion of pain relief
B) Disorder/specific disability
C) Functional improvement
D) Allocation of eligible and non-eligible patients to return to work
E) Ability to work
F) Psychological assessment or improvement

Adapted and modified from ref 33 evaluations (38-44).

\section{Methodological Quality}

A study of ventral epidural adhesiolysis (42), an inappropriate procedure (43), a retrospective evaluation of spinal stenosis (40), a publication from non peer-reviewed literature (41), and an abstract (44) published in 1993 were not included due to multiple deficiencies, leading to exclusion due to inability to meet inclusion/exclusion criteria, or inability to meet at least $50 \%$ of the methodological quality criteria.

Detailed review of reports revealed the two publications by Heavner et al (34) and Racz et al (35) were of the same study, they were considered as one study (34). Thus, a total of 3 studies by Heavner et al (34), Manchikanti et al $(36,37)$ were included.

The observational reports included 3 retrospective reports $(38-40)$. Of these 2 were included $(38,39)$.

Methodological criteria are shown in Tables 6 and 7.

\section{Descriptive Characteristics}

All the studies included in the evidence synthesis described the baseline characteristics $(34,36-39)$. Three randomized trials $(34,36,37)$ had similar patient characteristics. Manchikanti et al 


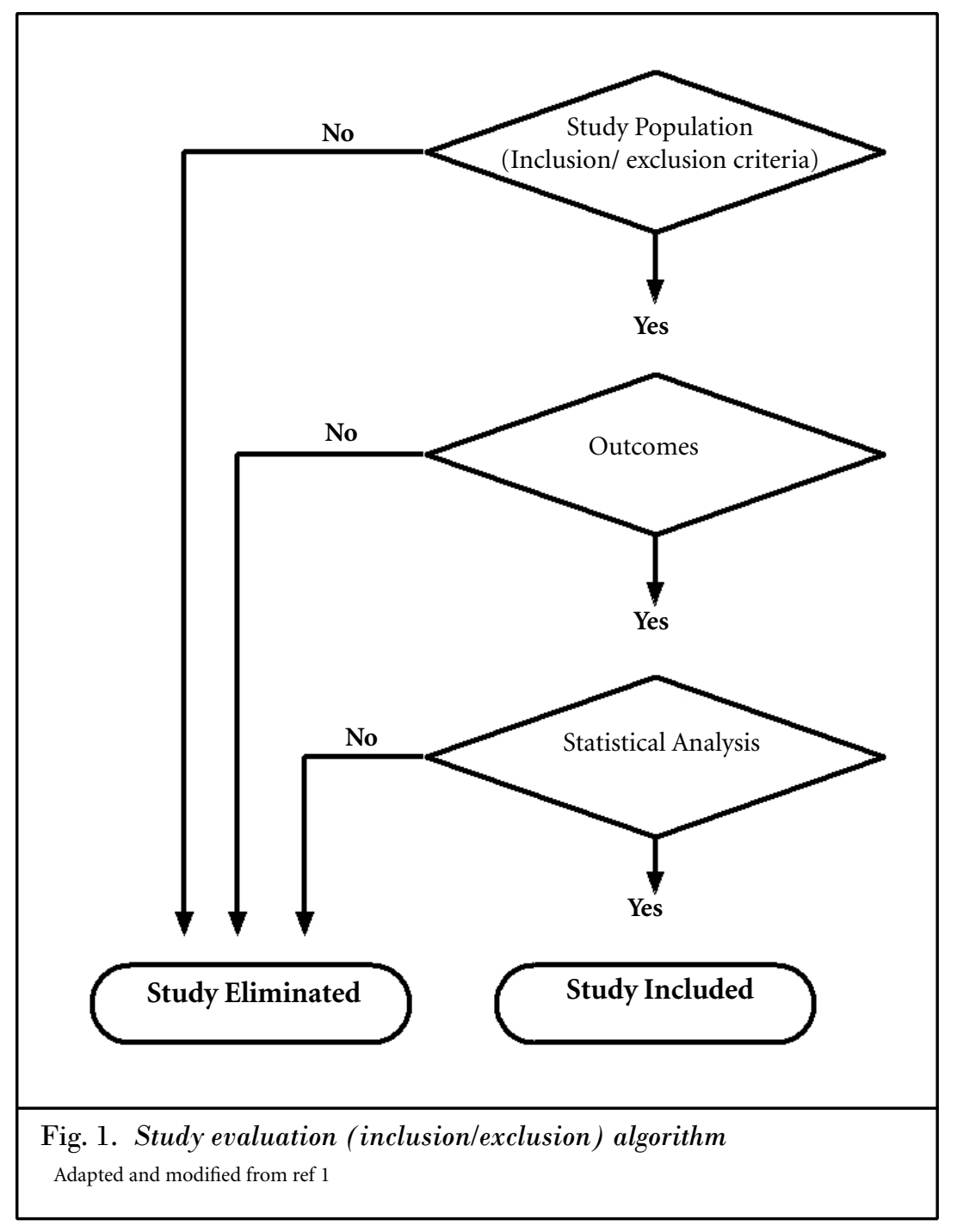

Table 5. Designation of levels of evidence

\begin{tabular}{|l|l|}
\hline Level I & $\begin{array}{l}\text { Conclusive: Research-based evidence with multiple relevant and high-quality } \\
\text { scientific studies or consistent reviews of meta-analyses }\end{array}$ \\
\hline Level II & $\begin{array}{l}\text { Strong: Research-based evidence from at least one properly designed randomized, } \\
\text { controlled trial; or research-based evidence from multiple properly designed } \\
\text { studies of smaller size; or multiple low quality trials. }\end{array}$ \\
\hline Level III & $\begin{array}{l}\text { Moderate: } \\
\text { a) Evidence obtained from well-designed pseudorandomized controlled trials } \\
\text { (alternate allocation or some other method); } \\
\text { b) evidence obtained from comparative studies with concurrent controls } \\
\text { and allocation not randomized (cohort studies, case-controlled studies, or } \\
\text { interrupted time series with a control group); } \\
\text { c) evidence obtained from comparative studies with historical control, two or } \\
\text { more single-arm studies, or interrupted time series without a parallel control } \\
\text { group. }\end{array}$ \\
\hline Level IV & $\begin{array}{l}\text { Limited: Evidence from well-designed nonexperimental studies from more than } \\
\text { one center or research group; or conflicting evidence with inconsistent findings } \\
\text { in multiple trials }\end{array}$ \\
\hline LevelV & $\begin{array}{l}\text { Indeterminate: Opinions of respected authorities, based on clinical evidence, } \\
\text { descriptive studies, or reports of expert committees. }\end{array}$ \\
\hline
\end{tabular}

Adapted and modified from ref 1
$(36,37)$ also reported proportion of the patients included with history of previous surgery, which ranged from $64 \%$ to $72 \%$ in all intervention groups. Patients in all 3 studies have failed multiple conservative modalities of treatments including fluoroscopically directed epidural steroid injections.

Among the 2 observational reports included $(38,39)$, patient demographics were described in both studies. However, the proportion of patients in Group II was $37 \%$ compared to $65 \%$ in Group I. In addition, in this study (38), patients following work-related injury were also lower in Group II with $30 \%$ whereas it was $50 \%$ in Group I. Duration of pain was also longer in Group II compared to Group I. Patients in this study in Group I received adhesiolysis and hypertonic saline neurolysis on two consecutive days with catheter in place for the second day. In contrast, Group II patients received a single day procedure with percutaneous adhesiolysis, as well as hypertonic saline neurolysis. In another retrospective evaluation, only patients with post lumbar laminectomy were included (39).

The number of patients also varied with a total of 59 subjects in one study with patients divided into 4 groups of 17 , $15,17,10$ (34) receiving 4 separate types of interventions; a total of 75 patients with 25 patients in each group (36); a total of 45 patients with 15 patients in Group I receiving conservative management, and 30 patients in Group II receiving intervention with percutaneous adhesiolysis and hypertonic saline neurolysis. Among the observational studies, one study compared a 1-day procedure to a 2-day procedure (38), whereas a second study compared percutaneous adhesiolysis to spinal endoscopic adhesiolysis (39).

Heavner et al (34) compared various types of solutions after the adhesiolysis was performed. Group A consisted of patients receiving a combination of hyaluronidase and hypertonic saline, Group $B$ consisted of patients hypertonic sodium chloride solution, Group C consisted of patients receiving isotonic saline solution, whereas, Group D consisted of patients receiving hyaluronidase and isotonic saline solution. Manchikanti et al (36) divided 100 patients randomly into 4 groups, with Group I consisting of a control group without adhesiolysis, with injection of local anesthetic, steroid, and normal saline; Group II consisting of pa- 
Table 6. Results of randomized trials of percutaneous adhesiolysis and hypertonic saline neurolysis

\begin{tabular}{|c|c|c|c|c|c|}
\hline Study/Methods & Participants & Intervention(s) & Outcome(s) & Result(s) & Conclusion(s) \\
\hline $\begin{array}{l}\text { Manchikanti et al (36) } \\
\text { A randomized, double } \\
\text { blind trial } \\
\text { AHRQ criteria } \\
\quad 10 / 10 \\
\text { Cochrane review } \\
\text { criteria } 10 / 10\end{array}$ & $\begin{array}{l}75 \text { patients were evaluated } \\
25 \text { patients in Group I } \\
\text { served as controls and were } \\
\text { with catheterization but no } \\
\text { adhesiolysis. } \\
25 \text { patients in Group } \\
\text { II were treated with } \\
\text { catheterization, } \\
\text { adhesiolysis, followed } \\
\text { by injection of local } \\
\text { anesthetic, normal saline, } \\
\text { and steroid. } \\
25 \text { patients in Group III } \\
\text { consisted of adhesiolysis } \\
\text { followed by injection of } \\
\text { local anesthetic, hypertonic } \\
\text { saline, and steroid. }\end{array}$ & $\begin{array}{l}\text { Experimental groups: } \\
\text { Adhesiolysis, } \\
\text { hypertonic saline } \\
\text { neurolysis, steroid } \\
\text { and local anesthetic } \\
\text { and adhesiolysis, } \\
\text { normal saline, } \\
\text { steroid. } \\
\text { Control group: } \\
\text { Catheterization and } \\
\text { no adhesiolysis. } \\
\end{array}$ & $\begin{array}{l}\text { Timing: } 3 \text { months, } \\
6 \text { months and } 12 \\
\text { months } \\
\text { Outcome measures: } \\
\text { VAS pain scale, } \\
\text { Oswestry } \\
\text { Disability Index 2.0, } \\
\text { work status, opioid } \\
\text { intake, range of } \\
\text { motion measurements } \\
\text { and psychological } \\
\text { evaluation } \\
\text { by P-3 }\end{array}$ & $\begin{array}{l}72 \% \text { of patients } \\
\text { in Group III } \\
\text { (adhesiolysis } \\
\text { and hypertonic } \\
\text { neurolysis), } 60 \% \text { of } \\
\text { patients in Group II } \\
\text { (adhesiolysis only), } \\
\text { compared to 0\% in } \\
\text { Group I (control) } \\
\text { showed significant } \\
\text { improvement at } \\
12 \text {-month follow-up. }\end{array}$ & $\begin{array}{l}\text { Positive short } \\
\text { term and long } \\
\text { term relief }\end{array}$ \\
\hline $\begin{array}{l}\text { Heavner et al (34) } \\
\text { A randomized, double } \\
\text { blind trial } \\
\text { AHRQ criteria } \\
7 / 10 \\
\text { Cochrane review } \\
\text { criteria } 7 / 10\end{array}$ & $\begin{array}{l}59 \text { patients with chronic } \\
\text { intractable low back pain. } \\
\text { All the patients failed } \\
\text { conservative management, } \\
\text { along with fluoroscopically } \\
\text { directed epidural steroid } \\
\text { injections. }\end{array}$ & $\begin{array}{l}\text { Group I: hypertonic } \\
\text { saline plus } \\
\text { hyaluronidase } \\
\text { Group II: hypertonic } \\
\text { saline } \\
\text { Group III: isotonic } \\
\text { saline }(0.9 \% \mathrm{NaCl}) \\
\text { Group IV: isotonic } \\
\text { saline plus } \\
\text { hyaluronidase }\end{array}$ & $\begin{array}{l}\text { Timing: } 4 \text { weeks, } 3 \\
\text { months, } 6 \text { months and } \\
12 \text { months } \\
\text { Outcome measures: } \\
\text { Pain relief }\end{array}$ & $\begin{array}{l}\text { Initially } 83 \% \\
\text { of the patients } \\
\text { showed significant } \\
\text { improvement } \\
\text { compared to } 49 \% \\
\text { of the patients at } \\
3 \text { months, } 43 \% \text { of } \\
\text { the patients at } 6 \\
\text { months, and } 49 \% \\
\text { of the patients at } 12 \\
\text { months. }\end{array}$ & $\begin{array}{l}\text { Positive short- } \\
\text { term and long- } \\
\text { term relief }\end{array}$ \\
\hline $\begin{array}{l}\text { Cochrane review } \\
\text { criteria - } \\
5 / 10 \\
\text { AHRQ criteria } \\
6 / 10\end{array}$ & $\begin{array}{l}45 \text { patients were evaluated. } \\
15 \text { patients in group I were } \\
\text { treated conservatively. } \\
30 \text { patients in group II were } \\
\text { treated with percutaneous } \\
\text { epidural adhesiolysis } \\
\text { and hypertonic saline } \\
\text { neurolysis. }\end{array}$ & $\begin{array}{l}\text { Experimental group: } \\
\text { Adhesiolysis, } \\
\text { hypertonic saline } \\
\text { neurolysis and } \\
\text { epidural steroid } \\
\text { injection, one or more } \\
\text { occasions. } \\
\text { Control group: } \\
\text { Physical therapy } \\
\text { exercise program and } \\
\text { medication. }\end{array}$ & $\begin{array}{l}\text { Timing: } 1 \text { month, } 3 \\
\text { months, } 6 \text { months, } 1 \\
\text { year. } \\
\text { Outcome measures: } \\
\text { Pain relief, functional } \\
\text { status, psychological } \\
\text { status, employment } \\
\text { status. }\end{array}$ & $\begin{array}{l}\text { Experimental } \\
\text { group showed } \\
\text { improvement } \\
\text { with pain relief in } \\
97 \% \text { at } 3 \text { months, } \\
93 \% \text { at } 6 \text { months, } \\
\text { and } 47 \% \text { of the } \\
\text { patients at } 1 \\
\text { year. Generalized } \\
\text { anxiety disorder, } \\
\text { somatization } \\
\text { disorder, } \\
\text { average pain, } \\
\text { and functional } \\
\text { status improved } \\
\text { significantly in } \\
\text { Group II. }\end{array}$ & $\begin{array}{l}\text { Positive short } \\
\text { term and long } \\
\text { term relief }\end{array}$ \\
\hline
\end{tabular}

tients undergoing adhesiolysis, with injection of local anesthetic, steroid, and normal saline; and Group III consisting of patients undergoing adhesiolysis, as well as injection of $10 \%$ sodium chloride solution, in addition to local anesthetic and steroid. Heavner et al (34) evaluated with a procedure lasting for 3 days where the catheter was inserted on the first day and the drugs were injected on the second and third day. Manchikanti et al $(34,37)$ evaluated one-day adhesiolysis.

Outcome parameters by Heavner et al (34) included short-form McGill Pain
Questionnaire and Visual Analog Scale for back pain and leg pain. Manchikanti et al (36) utilized VAS pain scale, Oswestry Disability Index 2.0, work status, opioid intake, range of motion measurement, and psychological evaluation by Pain Patient Profile.

Outcome measures included in the third randomized clinical trial (37) were significant pain relief $(\geq 50 \%)$ cumulative pain relief, physical health, mental health, functional status, narcotic intake, psychological status, and return to employment. In the observational reports $(38,39)$, au- thors evaluated significant pain relief, cumulative pain relief with multiple procedures, and cost effectiveness.

Manchikanti et al (37), included 45 patients with 15 patients in the control group, who were treated with conservative modalities of treatments, and $30 \mathrm{pa}$ tients in Group II, who were treated with percutaneous epidural adhesiolysis and hypertonic saline neurolysis.

Both the observational studies (38, 39) evaluated patients with 1-day adhesiolysis and hypertonic saline neurolysis, whereas, one study (38) evaluated patients 
Table 7. Results of published reports of prospective and retrospective evaluations of adhesiolysis and hypertonic saline neurolysis

\begin{tabular}{|c|c|c|c|c|c|}
\hline Study/Methods & Participants & Intervention(s) & Outcome(s) & Result(s) & Conclusion(s) \\
\hline $\begin{array}{l}\text { Manchikanti et al (38) } \\
\text { A retrospective } \\
\text { randomized evaluation } \\
\text { AHRQ criteria } \\
4 / 8\end{array}$ & $\begin{array}{l}\text { A retrospective } \\
\text { randomized evaluation } \\
\text { of the effectiveness } \\
\text { of 1-day adhesiolysis } \\
\text { and hypertonic saline } \\
\text { neurolysis in } 129 \\
\text { patients. }\end{array}$ & $\begin{array}{l}\text { Adhesiolysis, } \\
\text { hypertonic saline } \\
\text { neurolysis and } \\
\text { injection of steroid }\end{array}$ & $\begin{array}{l}\text { Timing: } \\
4 \text { weeks, } \\
3 \text { months, } \\
6 \text { months, } \\
12 \text { months } \\
\text { Outcome } \\
\text { measures: } \\
\text { Pain relief }\end{array}$ & $\begin{array}{l}\text { Initial relief was reported in } \\
79 \% \text { of the patients with } 68 \% \\
\text { of the patients reporting relief } \\
\text { at } 3 \text { months, } 36 \% \text { at } 6 \text { months } \\
\text { and } 13 \% \text { at } 12 \text { months with } 1 \\
\text { injection. }\end{array}$ & $\begin{array}{l}\text { Positive short-term } \\
\text { and negative long- } \\
\text { term relief }\end{array}$ \\
\hline $\begin{array}{l}\text { Manchikanti et al (39) } \\
\text { A retrospective } \\
\text { evaluation of } 60 \text { post } \\
\text { lumbar laminectomy } \\
\text { patients with chronic } \\
\text { low back pain } \\
\text { AHRQ criteria } \\
4 / 8\end{array}$ & $\begin{array}{l}60 \text { post lumbar } \\
\text { laminectomy patients } \\
\text { were included after } \\
\text { failure of conservative } \\
\text { management }\end{array}$ & $\begin{array}{l}\text { Adhesiolysis, } \\
\text { hypertonic saline } \\
\text { neurolysis and } \\
\text { injection of } \\
\text { steroid }\end{array}$ & $\begin{array}{l}\text { Timing: } \\
3 \text { months, } \\
6 \text { months, } \\
12 \text { months } \\
\text { Outcome } \\
\text { measures: } \\
\text { Pain relief }\end{array}$ & $\begin{array}{l}\text { With multiple injections, initial } \\
\text { relief was seen in } 100 \% \text { of the } \\
\text { patients, however it declined } \\
\text { to } 90 \% \text { at } 3 \text { months, } 72 \% \text { at } 6 \\
\text { months, and } 52 \% \text { at } 1 \text { year. }\end{array}$ & $\begin{array}{l}\text { Positive short- } \\
\text { term and long- } \\
\text { term relief }\end{array}$ \\
\hline
\end{tabular}

also with a 2-day adhesiolysis.

Randomization was adequate in all 3 studies. Blinding was adequate in 2 studies $(34,36)$.

Statistical analysis included Fisher's Exact Test (2-by-2 tables) and the generalized Fisher's Exact Test (4-by-2 tables) by Heavner et al (34); chi-squared test, Fisher's Exact Test, student's “t” test, paired " $\mathrm{t}$ " test, and intent-to-treat analysis were utilized by Manchikanti et al (36); and chi-squared statistic, student's " $\mathrm{t}$ " test, and paired " $\mathrm{t}$ " test were utilized by Manchikanti et al (37). Appropriate statistical evaluations were utilized by 2 -by2 chi-squared tests and student "t" test in observational reports $(38,39)$.

Description of results of published studies of percutaneous adhesiolysis and hypertonic saline neurolysis are shown in Table 6.

\section{Effectiveness}

Effectiveness was evaluated based on the questions sought to be answered.

1) Is percutaneous adhesiolysis an effective treatment?

All three randomized studies $(34,36,37)$ evaluated the effectiveness of percutaneous adhesiolysis. Subsequently 2 retrospective evaluations $(38,39)$ also evaluated percutaneous adhesiolysis. Heavner et al (34) had no control group. However, they assessed effectiveness of adhesiolysis by means of each patient being their own control, as all the patients failed previously fluoroscopically directed epidural ste- roid injections, including other conservative modalities of treatments. Manchikanti et al (36) evaluated the role of adhesiolysis, specifically with a control group receiving epidural steroid injection only where the catheter was inserted without adhesiolysis, followed by injection of epidural steroid and local anesthetic injection with sodium chloride solution injection with catheter in place in the sacral region (S2 or S3), with Group II and Group III undergoing adhesiolysis. The third study (37) had no control group and intervention group consisted of adhesiolysis and hypertonic saline neurolysis. All three studies showed positive results for short-term improvement and long-term improvement with adhesiolysis. All three studies showed significant improvement, either over the control group $(36,37)$, or patients as their own controls (34).

Among the observational reports, both $(38,39)$ were positive for short-term relief, whereas, only one (39) was positive for long-term relief.

2) Is percutaneous adhesiolysis superior to epidural steroid injections?

Heavner et al (34) and Manchikanti et al (37) demonstrated that percutaneous adhesiolysis was superior to epidural steroid injections and provided both shortterm and long-term improvement in managing chronic low back and lower extremity pain. Manchikanti et al
(36) evaluated the issue specifically with a control group where patients only received epidural steroid injection in a random and blinded manner. These studies showed the clear superiority of adhesiolysis alone and with hypertonic saline neurolysis, over epidural steroid injections. Other studies (37-39) also reveal evidence of successful pain relief with adhesiolysis with inclusion of patients after failure of fluoroscopically directed epidural steroid injections.

3) Does the addition of hypertonic sodium chloride solution improve outcomes?

Heavner et al (34) evaluated the effect of hypertonic sodium chloride solution and compared it with isotonic sodium chloride solution and hyaluronidase. They noted lack of significant differences among the groups. Manchikanti et al (36) evaluated the effectiveness of adhesiolysis alone or with hypertonic saline injection. In this study, authors demonstrated significant improvement with addition of hypertonic sodium chloride solution following adhesiolysis compared to adhesiolysis alone when they compared only the successful patients. When all the patients, utilizing intent-to-treat analysis was utilized, the differences were not significant.

4) Does the addition of hyaluronidase improve outcomes?

Heavner et al (34) evaluated the effectiveness of hyaluronidase with 
comparison to isotonic sodium chloride solution or mixed with hypertonic sodium chloride solution. However, they noted no significant differences among the groups.

5) Is percutaneous adhesiolysis a safe procedure?

Heavner et al (34) reported no adverse effects. Manchikanti et al (36-39) reported one subarachnoid block in Group II of 25 patients in this particular group and 75 patients in the study (36), suspicion of infection in one case (37), subarachnoid blockade in $2 \%$ or 5 patients, serious infection in one patient with development of an abscess, suspicion of infection in $2 \%$ of the patients or 4 cases in a retrospective evaluation (38); subarachnoid puncture in 4 out of 178 procedures, infection in one of 178 procedures and suspicion of infection in 8 of 178 procedures (39). Manchikanti et al (37-39) also reported minor complications such as rash, itching, etc. However, none of the studies have reported any incidents of arachnoiditis, paralysis, weakness, bladder disturbances, or other serious complications.

\section{Level of Evidence}

All randomized trials $(34,36,37)$ showed positive short-term and longterm relief. Of the two retrospective evaluations, both $(38,39)$ showed short-term improvement, whereas long-term improvement was seen only in one study (39). The level of evidence was designated as described in Table 5. Based on this illustration there was research-based evidence from three properly designed randomized controlled trials. Strong or level 2 evidence consisted of research-based evidence from at least one properly designed randomized, controlled trial; or researchbased evidence from multiple properly designed studies of smaller size; or multiple low quality trials.

The evidence for percutaneous adhesiolysis is strong for short-term and longterm relief with repeat interventions, in chronic refractory low back and lower extremity pain secondary to post lumbar laminectomy syndrome or lumbar epidural fibrosis. The evidence for percutaneous adhesiolysis as a better treatment than epidural steroid injections is also strong for short-term and long-term improvement. However, the evidence for addition of hypertonic sodium chloride solution providing better outcomes, is moderate for short-term and long-term improvement. Finally, the evidence for improved outcomes following addition of hyaluronidase is negative.

\section{Spinal Endoscopic Adhesiolysis}

Our search strategy yielded a total of 112 articles. Relevant reports studying spinal endoscopic adhesiolysis were eight. Two randomized, double blind evaluations $(45,46), 3$ prospective evaluations (47-49), and 3 retrospective evaluations $(39,50,51)$, and multiple case reports were available for review.

\section{Methodological Quality}

Of the two randomized, doubleblind evaluations one of them was a preliminary report (45), whereas the second study (46) described one year follow-up. Hence, they were considered as a single randomized double-blind trial (46).

The 3 of 3 prospective evaluations, met the criteria for inclusion (47-49). Among the retrospective evaluations, two reports $(39,50)$ were included as they met the inclusion criteria. One report (51) due to insufficient data and failure to meet inclusion criteria was excluded. Table 8 shows details of studies included.

\section{Descriptive Characteristics}

Demographic characteristics were described in all the studies. There were no significant differences noted in any of the studies among the demographic characteristics. Patients with previous surgery were $73 \%$ in Group I and $84 \%$ in Group II in the study by Manchikanti et al (46). Igarashi et al (48) evaluated patients with spinal stenosis. All other studies included post lumbar laminectomy patients, whereas, one retrospective evaluation (39) included only post lumbar laminectomy patients who also have failed percutaneous adhesiolysis.

Inclusion criteria was uniform across all the reports with failure to respond to conservative modalities of treatments, as well as fluoroscopically directed epidural steroid injections. Manchikanti et al $(39,46,50)$ used inclusion criteria as of patients to have failed percutaneous adhesiolysis prior to performing spinal endoscopic adhesiolysis. Manchikanti et al (46) also identified proportion of patients with epidural fibrosis as $73 \%$ in Group I receiving epidural steroid injection and
$84 \%$ in Group II undergoing spinal endoscopic adhesiolysis.

Interventions included spinal endoscopic adhesiolysis with administration of local anesthetic and steroids in all the studies. In the randomized, double-blind trial by Manchikanti et al (46), the control group received advancement of the scope into sacral region (S2 or S3) followed by injection of steroid and local anesthetic, whereas, intervention group received spinal endoscopic adhesiolysis in the targeted area along with targeted delivery of local anesthetic and steroids.

Outcomes included Visual Analogue Scale, Oswestry Disability Index 2.0, range of motion evaluation, psychological evaluation by Pain Patient Profile, opioid intake, and return to work by Manchikanti et al (46); whereas, pain relief was the major outcome measurement in all the other reports. Geurts et al (47) also measured changes in employment status. Further, they utilized an independent evaluator.

Statistical methods included student's " $t$ " test, chi-squared test, Fisher's Exact Test, paired " $t$ " test, and Wilcoxon Signed-Rank Test (46); Man-Whitney-U tests (48); paired " $\mathrm{t}$ " tests and an adapted last-observation-carried-forward (LOCF) analysis (47); and $2 \times 2$ chi-squared test and student " $t$ " test (39).

\section{Effectiveness}

The randomized trial (46) showed significant improvement in pain relief, as well as multiple other parameters including return to work at 3 months, 6 months, and 1 year. The prospective evaluations (47-49) also showed improvement. Both the retrospective evaluations $(39,50)$ included in the analysis showed positive short-term and long-term results. Details of the included studies are illustrated in Table 8.

\section{Safety}

Complications of endoscopic adhesiolysis were described as one subarachnoid puncture and block in endoscopy group (46) of 50 patients; post dural puncture headache in 3 of 21 patients (47); no deterioration of motor or sensory deficits (48); subarachnoid puncture of 7 of 77 procedures; suspicion of infection in 8 of 77 procedures (39); subarachnoid puncture in 8 of 112 procedures; infection in 2 of 112 procedures; and suspected infection in 6 of 112 patients (50). Minor complications such as rash, itching, in- 
Table 8. Description of randomized and observational studies of spinal endoscopy

\begin{tabular}{|c|c|c|c|c|c|}
\hline Study/Methods & Participants & Intervention(s) & Outcome(s) & Result(s) & Conclusion(s) \\
\hline $\begin{array}{l}\text { Manchikanti et al (46) } \\
\text { A prospective, } \\
\text { randomized, double- } \\
\text { blind trial } \\
\text { AHRQ criteria } \\
10 / 10 \\
\text { Cochrane review criteria } \\
10 / 10\end{array}$ & $\begin{array}{l}\text { A total of } 83 \text { patients } \\
\text { were evaluated, with } 33 \\
\text { patients in Group I and } \\
50 \text { patients in Group II. } \\
\text { Group I served as the } \\
\text { control with endoscopy } \\
\text { into the sacral canal } \\
\text { without adhesiolysis, } \\
\text { followed by injection } \\
\text { of local anesthetic and } \\
\text { steroid. } \\
\text { Group II consisted } \\
\text { of spinal endoscopic } \\
\text { adhesiolysis, followed } \\
\text { by injection of local } \\
\text { anesthetic and steroid. } \\
73 \% \text { of the patients } \\
\text { in Group I and } 84 \% \\
\text { of the patients in } \\
\text { Group II were of post } \\
\text { lumbar laminectomy } \\
\text { syndrome and had } \\
\text { MRI evidence of } \\
\text { epidural fibrosis. }\end{array}$ & $\begin{array}{l}\text { In Group I, guide wire } \\
\text { and a } 0.8 \mathrm{~mm} \text { fiberoptic } \\
\text { spinal endoscopic } \\
\text { video guided system } \\
\text { was introduced and } \\
\text { advanced until the } \\
\text { tip was positioned S3. } \\
\text { Injections included } \\
10 \mathrm{ml} \text { of } 1 \% \text { lidocaine } \\
\text { and } 6 \mathrm{mg} \text { to } 12 \mathrm{mg} \\
\text { of Celestone or } 40 \\
\text { mg to } 80 \text { mg of } \\
\text { methylprednisolone. } \\
\\
\text { In Group II, spinal } \\
\text { endoscope was advanced } \\
\text { to the level of suspected } \\
\text { pathology. Adhesiolysis } \\
\text { was carried out. } \\
\text { Injections included } 10 \\
\text { ml of lidocaine } 1 \% \text {, } \\
\text { preservative free, mixed } \\
\text { with } 6 \text { mg to } 12 \text { mg of } \\
\text { betamethasone acetate } \\
\text { or } 40 \text { mg to } 80 \text { mg of } \\
\text { methylprednisolone. }\end{array}$ & $\begin{array}{l}\text { Timing: } \\
1 \text { month, } 3 \text { months, } \\
6 \text { months, and } 12 \\
\text { months } \\
\text { Outcome measures: } \\
\text { Pain relief by visual } \\
\text { analog scale } \\
\text { Significant pain } \\
\text { relief } 50 \% \text { or greater. } \\
\text { Oswestry Disability } \\
\text { Index } 2.0 \\
\text { Work status } \\
\text { Opioid intake } \\
\text { Range of motion } \\
\text { measurement } \\
\text { Psychological } \\
\text { evaluation } \\
\text { Return to work }\end{array}$ & $\begin{array}{l}\text { Intention to treat analysis was } \\
\text { performed. } \\
\text { Among the } 50 \text { patients in the treatment } \\
\text { group with spinal endoscopic } \\
\text { adhesiolysis } 80 \% \text { at } 3 \text { months, } 56 \% \text { at } 6 \\
\text { months, and } 48 \% \text { at } 12 \text { months showed } \\
\text { significant improvement without } \\
\text { adverse events. } \\
\text { In control group improvement was } \\
\text { noted only at one month. } \\
\text { Group II patients showed improvement } \\
\text { in Oswestry Disability Scores, } \\
\text { psychological status, reduced opioid } \\
\text { intake, and increased employment. }\end{array}$ & $\begin{array}{l}\text { Positive short- } \\
\text { term and long- } \\
\text { term relief. }\end{array}$ \\
\hline $\begin{array}{l}\text { Igarashi et al (48) } \\
\text { AHRQ Score } \\
6 / 8\end{array}$ & $\begin{array}{l}58 \text { patients with } \\
\text { degenerative } \\
\text { lumbar spinal } \\
\text { stenosis divided into } \\
\text { monosegmental (34) } \\
\text { and multisegmental } \\
\text { (24) groups. }\end{array}$ & $\begin{array}{l}\text { Epiduroscopy including } \\
\text { adhesiolysis by injection } \\
\text { of saline, and injection } \\
\text { of steroids/local } \\
\text { anesthetics. }\end{array}$ & $\begin{array}{l}\text { Timing: } \\
\text { up to } 12 \text { months } \\
\text { Outcome measures: } \\
\text { Amount of fatty } \\
\text { tissue, degree of } \\
\text { vascularity, relief } \\
\text { of lower back pain, } \\
\text { relief of leg pain }\end{array}$ & $\begin{array}{l}\text { Amount of fatty tissue and degree } \\
\text { of vascularity where greater in the } \\
\text { monosegmental group. Relief of } \\
\text { low back pain was observed up to } 12 \\
\text { months in both groups. Relief of leg } \\
\text { pain was evident up to } 12 \text { months } \\
\text { in monosegmental group, and up to } \\
\text { 3months in multisegmental group. }\end{array}$ & $\begin{array}{l}\text { Positive short- } \\
\text { term and long- } \\
\text { term relief }\end{array}$ \\
\hline $\begin{array}{l}\text { Geurts et al (47) } \\
\text { A prospective } \\
\text { observational study } \\
\text { AHRQ Score } \\
6 / 8\end{array}$ & $\begin{array}{l}20 \text { chronic low back } \\
\text { pain patients, the } \\
\text { majority of them } \\
\text { with post lumbar } \\
\text { laminectomy } \\
\text { syndrome failing } \\
\text { to respond to } \\
\text { other modalities of } \\
\text { treatments. }\end{array}$ & $\begin{array}{l}\text { Epiduroscopy with } \\
\text { adhesiolysis and target } \\
\text { delivery of } 120 \mathrm{mg} \text { of } \\
\text { methylprednisolone } \\
\text { acetate, } 600 \mathrm{IU} \text { of } \\
\text { hyaluronidase, and } 150 \\
\text { mcg of Clonidine. }\end{array}$ & $\begin{array}{l}\text { Timing: } \\
3,6,9 \text { and } 12 \\
\text { months. } \\
\text { Outcome measures: } \\
\text { Adhesiolysis and } \\
\text { pain relief }\end{array}$ & $\begin{array}{l}19 \text { of } 20 \text { patients studied showed } \\
\text { adhesions via epiduroscopy. } 55 \% \text { of } \\
\text { the patents experienced significant } \\
\text { pain relief at } 3 \text { months, } 40 \% \text { at } 6 \\
\text { months, and } 35 \% \text { of the patients at } \\
12 \text { months. Mean VAS at } 3 \text { months } \\
\text { was significantly reduced that } \\
\text { persisted at } 12 \text { months. }\end{array}$ & $\begin{array}{l}\text { Positive short- } \\
\text { term and } \\
\text { long-term } \\
\text { relief }\end{array}$ \\
\hline $\begin{array}{l}\text { Richardson et al (49) } \\
\text { A prospective case } \\
\text { series } \\
\text { AHRQ Score } \\
4 / 8\end{array}$ & $\begin{array}{l}34 \text { patients suffering } \\
\text { with chronic, severe } \\
\text { low back pain with } \\
50 \% \text { of the patients } \\
\text { having failed back } \\
\text { surgery syndrome. }\end{array}$ & $\begin{array}{l}\text { Epidural adhesiolysis } \\
\text { and target delivery of } \\
\text { steroid. Adhesiolysis } \\
\text { followed by injection } \\
\text { of bupivacaine, Depo- } \\
\text { Medrol, and Clonidine. }\end{array}$ & $\begin{array}{l}\text { Timing: } \\
\text { 1,2,6, and } 12 \\
\text { months } \\
\text { Outcome measures: } \\
\text { Pain relief }\end{array}$ & $\begin{array}{l}\text { A significant number of patients } \\
\text { showed pain relief at all levels. They } \\
\text { also reported that epidural adhesions } \\
\text { were present in } 100 \% \text { of the patients, } \\
\text { with } 41 \% \text { having dense adhesions. } \\
\text { Follow-up over a } 12 \text { month period } \\
\text { showed statistically significant } \\
\text { reductions in pain scores and } \\
\text { disability. }\end{array}$ & $\begin{array}{l}\text { Positive short- } \\
\text { term and } \\
\text { long-term } \\
\text { relief }\end{array}$ \\
\hline $\begin{array}{l}\text { Manchikanti et al (39) } \\
\text { A retrospective } \\
\text { evaluation in post } \\
\text { lumbar laminectomy } \\
\text { syndrome } \\
\text { AHRQ Score } \\
4 / 8\end{array}$ & $\begin{array}{l}60 \text { patients with post } \\
\text { lumbar laminectomy } \\
\text { syndrome }\end{array}$ & $\begin{array}{l}\text { Spinal endoscopy with } \\
\text { targeted delivery of } \\
\text { steroid. }\end{array}$ & $\begin{array}{l}\text { Timing: } \\
1,3,6 \text {, and } 12 \\
\text { months } \\
\text { Outcome measures: } \\
\text { Pain relief }\end{array}$ & $\begin{array}{l}100 \% \text { of the patients reported relief } \\
\text { initially, which declined to } 75 \% \text { at } 3 \\
\text { months, } 40 \% \text { at } 6 \text { months and } 22 \% \text { at } \\
12 \text { months. }\end{array}$ & $\begin{array}{l}\text { Positive short- } \\
\text { term and } \\
\text { long-term } \\
\text { relief }\end{array}$ \\
\hline $\begin{array}{l}\text { Manchikanti et al (50) } \\
\text { A retrospective } \\
\text { evaluation of spinal } \\
\text { endoscopy } \\
\text { AHRQ Score } \\
4 / 8\end{array}$ & $\begin{array}{l}85 \text { consecutive } \\
\text { patients underwent } \\
112 \text { epidural } \\
\text { endoscopic } \\
\text { procedures. }\end{array}$ & $\begin{array}{l}\text { Spinal endoscopy with } \\
\text { targeted delivery of } \\
\text { steroid. }\end{array}$ & $\begin{array}{l}\text { Timing: } \\
\text { 1,3,6, and } 12 \\
\text { months } \\
\text { Outcome measures: } \\
\text { Pain relief }\end{array}$ & $\begin{array}{l}100 \% \text { of the patients reported pain } \\
\text { relief initially. The relief decreased to } \\
94 \% \text { at } 1 \text { to } 2 \text { months, to } 77 \% \text { at } 2 \text { to } \\
3 \text { months, to } 52 \% \text { at } 3 \text { to } 6 \text { months, to } \\
21 \% \text { at } 6 \text { to } 12 \text { months and } 7 \% \text { after } \\
12 \text { months. }\end{array}$ & $\begin{array}{l}\text { Positive short- } \\
\text { term and } \\
\text { long-term } \\
\text { relief }\end{array}$ \\
\hline
\end{tabular}


creased discomfort, and neck pain were reported in some studies.

\section{Level of Evidence}

One randomized trial (46), 3 prospective trials (47-49) and 2 retrospective evaluations $(39,50)$ showed positive short-term and long-term results. The evidence synthesis for spinal endoscopy showed strong evidence for short-term relief and moderate evidence for longterm improvement. The evidence of effectiveness of spinal endoscopic adhesiolysis compared to epidural steroid injections is strong for short-term and longterm improvement. The evidence of spinal endoscopic adhesiolysis in patients after they have failed percutaneous adhesiolysis is strong. The evidence of effectiveness of spinal endoscopic adhesiolysis in lumbar spinal stenosis is moderate for short-term and limited for long-term improvement.

\section{Complications}

Our search strategy yielded a total of 358 articles. Only some relevant articles are included here. The complications related to percutaneous adhesiolysis and spinal endoscopy in the included reports are described in the results section.

The most common and worrisome complications of adhesiolysis and spinal endoscopy with lysis of adhesions are related to dural puncture, spinal cord compression, catheter shearing, intravascular injection, vascular injury, cerebral vascular or pulmonary embolus, infection, steroids, hypertonic saline, hyaluronidase, instrumentation with endoscope, and administration of high volumes of fluids potentially resulting in excessive epidural hydrostatic pressures, death and brain damage (26-30, 34-101). This may cause spinal cord compression, excessive intraspinal and intracranial pressures, epidural hematoma, bleeding, infection, increased intraocular pressures with resultant visual deficiencies, and even blindness and dural puncture. Unintended subarachnoid or subdural puncture with injection of local anesthetic or hypertonic saline is one of the major complications of the procedure with catheter adhesiolysis. Hypertonic saline injected into the subarachnoid space has been reported to cause cardiac arrhythmias, myelopathy, paralysis, and loss of sphincter control $(27,34,52)$. One report attributed arachnoiditis following epidural adhesiolysis with hypertonic sa- line, due to subarachnoid leakage of hypertonic saline (72). However, there were multiple variations in the technique and injection of hypertonic saline, (intraoperatively or injecting in spite of subarachnoid blockade), which may be responsible for these complications. While there are multiple reports with experience of hypertonic saline solution, there are no controlled reports of potential adverse effects $(26,27,34-42,44)$. Another specific complication of percutaneous epidural adhesiolysis is related to catheter shearing and its retention in the epidural space (78). Additionally, a troublesome complication is that of excessive intraspinal pressure development with its potential to affect both local and distant profusion, and resulting in visual changes and even blindness. Even though the incidence is rare, it appears that this would be much higher with spinal endoscopic procedures with a combination of high volumes of fluid and generation of high hydrostatic pressures (79). It is also possible with catheter based adhesiolysis if excessive amounts of fluids are injected rapidly. Spinal cord trauma or spinal cord or epidural hematoma formation is a catastrophic complication possible with both catheter based or endoscopic adhesiolysis; however, more so with endoscopic adhesiolysis. But, there are no such case reports in the literature. Understanding fluoroscopic imaging is crucial to avoid significant complications (80).

\section{DisCUSSION}

The literature identified in this systemic review clearly documents the role of epidural adhesions as a cause of many chronic pain disease states of the spine. It is not surprising that methods to disrupt the scarring can lead to improved outcomes particularly when this change in the anatomical relationships leads to improved access to the neural elements for depositing drugs. This access can be provided by adhesiolysis of the epidural space by the percutaneous route or by spinal endoscopic visualization. These methods are interventional pain management techniques that have a role in the treatment paradigm of the physician treating interventional pain.

In reviewing the studies in this review that have met the stringent criteria set forth by the authors, it appears that current techniques are valuable in cases of epidural scarring, resulting in chronic pain problems. The results must be looked at somewhat cautiously because of the variability in physician technique and procedural ability. More extensive work is needed to determine the characteristics of patients who may have the best outcomes with these techniques.

This systematic review provided strong evidence describing the role of percutaneous adhesiolysis, moderate evidence for injection of hypertonic sodium chloride solution, and negative evidence for injection of hyaluronidase in managing chronic, refractory, low back pain and radicular pain. This systematic review also showed moderate to strong evidence to indicate effectiveness of spinal endoscopic adhesiolysis in managing chronic, refractory, low back and lower extremity pain. This study showed limited to moderate evidence in managing lumbar spinal stenosis with spinal endoscopic adhesiolysis. However, this study showed no evidence of effectiveness of hyaluronidase. In addition, this study showed, percutaneous adhesiolysis and spinal endoscopic adhesiolysis are clearly superior to fluoroscopically directed epidural steroid injections. Further, this also demonstrates review modalities of an effective management of chronic, refractory low back and lower extremity pain, specifically secondary to post lumbar laminectomy syndrome and epidural fibrosis.

This systematic review with stringent inclusion and exclusion criteria as well as methodological quality, demonstrated that the technique of adhesiolysis overcomes the obstacle of being able to get various medications to a lesion specific site by placing the tip of a soft spring catheter within the scar or tip of the fiberoptic endoscope by opening the perineural space. Thus, the steroid and other solutions reach the appropriate site and provide anti-inflammatory effect, and neural blockade. This systematic evaluation showed three appropriately performed randomized trials $(34,36,37)$ of percutaneous adhesiolysis, and one well performed, randomized, double-blind trial of spinal endoscopic adhesiolysis (46). Further there were multiple prospective and retrospective evaluations. Majority of the studies met the stringent inclusion criteria and also methodological criteria. Majority of the publications showed positive short-term (less than 3 months) and longterm (3 months or longer) improvement in pain status and multiple other parameters. The variations in results may be ex- 
plained on various factors including technical expertise and the drugs injected.

The methodological quality and number of patients included in the studies may be criticized in the randomized trials of percutaneous adhesiolysis. Heavner et al (34) included 59 patients with chronic intractable low back pain. All the patients failed conservative management, along with fluoroscopically directed epidural steroid injections. Consequently these authors studied effect of isotonic saline, hypertonic saline plus hyaluronidase, and finally isotonic saline plus hyaluronidase. The patients functioned as their own controls for the purposes of adhesiolysis. They measured various outcomes at 4 weeks, 3 months, 6 months and 12 months. Their outcome measures included pain relief by visual analog scale. Of the 83 patients 24 patients were removed from the study before the injection series was completed. In addition authors also have not performed intention-totreat analysis. The results showed, $49 \%$ of the patients with significant improvement at 3 months, $43 \%$ at 6 months, and $49 \%$ at 12 months. However the study has been misinterpreted in the past due to lack of differences between various groups (102, 103). In this study (34), all the patients prior to being enrolled in the randomized, double-blind study failed to respond to many types of conservative modalities of treatment including fluoroscopically directed epidural steroid injections. Thus, this study provided evidence for effectiveness of adhesiolysis, but not for injection of hypertonic saline or hyaluronidase.

The second randomized trial of percutaneous adhesiolysis by Manchikanti et al (36) evaluated one day lumbar epidural adhesiolysis and hypertonic saline neurolysis in treatment of chronic low back pain with randomized, double-blind design. These authors studied a total of 75 patients with 25 patients in each group with 3 types of interventions. Group I served as controls with catheterization without adhesiolysis, followed by injection of local anesthetic, normal saline, and steroid. Group II consisted of catheterization and adhesiolysis followed by injection of local anesthetic, normal saline, and steroid. Group III consisted of adhesiolysis followed by injection of local anesthetic, hypertonic saline, and steroid. These authors also incorporated statistical analysis which included intentto-treat analysis. They included exten- sive outcome measures with visual analog pain scores, Oswestry Disability Index, work status, opioid intake, range of motion measurement, and psychological status. They defined significant pain relief as average relief of $50 \%$ or greater. Their results showed that significant improvement was seen in patients in Group II and Group III at 3 months, 6 months and 12 months, compared to baseline measurements, as well as compared to Group I without adhesiolysis. In this study, $72 \%$ of patients in Group III with adhesiolysis and hypertonic saline neurolysis $60 \%$ of patients in Group II with adhesiolysis only compared to $0 \%$ in Group I without adhesiolysis however with steroid injection showed significant improvement at 12 month follow-up. These authors also showed that the average number of treatments for one year were 2.76 in Group II and 2.16 in Group III. Duration of significant relief with the first procedure was $2.8 \pm 1.9$ months in Group II and $3.8 \pm$ 3.37 months in Group III. Consequently, authors of this review concur with the authors of the study which concluded that percutaneous adhesiolysis, with or without hypertonic saline neurolysis is an effective treatment for chronic low back pain.

The third randomized trial by Manchikanti et al (37) also showed positive results. In this study, forty-five patients were randomly assigned, with fifteen patients in the control group, or Group I, who were treated with conservative modalities of treatments, including medication, physical therapy, and an exercise program; and, thirty patients in Group II, who were treated with percutaneous epidural adhesiolysis and hypertonic saline neurolysis. The results of this study showed that cumulative relief, defined as relief greater than $50 \%$ with one to three injections, in the treatment group was $97 \%$ at 3 months, $93 \%$ at 6 months, and $47 \%$ at 1 year. They also demonstrated improvement in multiple parameters and cost-effectiveness of adhesiolysis.

Further, 2 of the 3 retrospective evaluations showed positive results for longterm improvement. Consequently the evidence is strong for short-term and long-term improvement in patients with chronic refractory lower extremity pain with percutaneous adhesiolysis.

For spinal endoscopic adhesiolysis, one randomized, double-blind evaluation (46) provided strong evidence for short-term improvement and moderate evidence for long-term improvement. This prospective, randomized, doubleblind trial (46) was conducted to determine the outcome of spinal endoscopic adhesiolysis to reduce pain and improve function and psychological status in patients with chronic refractory low back and lower extremity pain. Authors evaluated a total of 83 patients, with 33 patients in Group I and 50 patients in Group II. Group I served as the control with endoscope advanced to $\mathrm{S}_{3}$ or $\mathrm{S}_{2}$, without adhesiolysis followed by injection of local anesthetic and steroid. Group II consisted of spinal endoscopic adhesiolysis, followed by injection of local anesthetic and steroid. The results demonstrated significant improvement without adverse events in $80 \%$ of the patients at 3 months, $56 \%$ at 6 months and $48 \%$ at 12 months among the 50 patients in the treatment group. In contrast, control group failed to provide any significant improvement. These authors also showed that the average significant relief was $0.7 \pm 0.73$ months in the control group, whereas it was, $7.6 \pm 4.7$ months in the spinal endoscopy group. Significant improvements were seen in functional status as evaluated by Oswestry Disability Index, range of motion evaluation, psychological outcomes of depression, anxiety, and somatization, opioid intake with reduction in dosages, and finally return to employment.

In prospective trials of spinal endoscopic adhesiolysis, Igarashi et al (48) showed its effectiveness on low back and lower extremity pain specifically in patients with mono-segmental spinal stenosis, whereas multiple other authors also have shown consistently positive shortterm and long-term relief.

Even though there is a possibility of severe complications, reported complications were rare. Thus, moderate to strong evidence exists in favor of adhesiolysis as an interventional pain management technique, in managing chronic low back and lower extremity pain, refractory to conservative modalities of treatments including interventional techniques.

In current clinical practice spinal endoscopic fiberoptics allows for nerve root visualization, however this view is often hindered by haziness or scope fogging. Advancement of this technology to match that seen in laparoscopic abdominal would be very helpful in improving outcomes. Additional technological advanc- 
es would assist in reducing complications such as stroke, retinal bleeding and blindness. Additional advances are needed to reduce the incidence of dural leakage and nerve root injury. These changes could be achieved with improved visualization and improved catheter maneuverability and material. One of the major drawbacks of this review includes our inability to find diverse studies meeting inclusion criteria. The majority have been conducted by one or two groups of investigators. Thus, replication of these studies is essential.

A registry of patients undergoing these techniques could be beneficial in following long-term outcomes. In the studies we have noted in this review, three months is considered a good longterm outcome, but we do not find a credible amount of evidence based research to suggest the results of these patients over time in regard for the need of repeat procedures and additional spinal surgery.

\section{ConCLusion}

Both percutaneous and spinal endoscope assisted adhesiolysis appear to have reasonable basis for utilization based on a summary of the evidence. Based on the present systematic review there is strong evidence for percutaneous adhesiolysis and moderate to strong evidence for spinal endoscopic adhesiolysis in managing chronic refractory low back and lower extremity pain specifically of post lumbar laminectomy origin with epidural fibrosis.

\section{RefERENCES}

1. Manchikanti L, Staats PS, Singh V, Schultz DM, Vilims BD, Jasper JF, Kloth DS, Trescot AM, Hansen HC, Falasca TD, Racz GB, Deer T, Burton AW, Helm S, Lou L, Bakhit CE, Dunbar EE, Atluri SL, Calodney AK, Hassenbusch S, Feler CA. Evidence-based practice guidelines for interventional techniques in the management of chronic spinal pain. Pain Physician 2003; 6:3-80.

2. Carey TS, Garrett JM, Jackman A, Hadler N. Recurrence and care seeking after acute back pain. Results of along term follow up study. Med Care 1999; 37:157-164.

3. Wahlgren DR, Atkinson JH, Epping-Jordan JE, Williams RA, Pruitt SD, Klapow JC, Patterson TL, Grant I, Webster JS, Slater MA. One-year follow up of first onset low back pain. Pain 1997; 73:213-221.

4. Vingard E, Mortimer M, Wiktorin C, Pernold RPTG, Fredriksson K, Nemeth G, Alfredsson L; Musculoskeletal Intervention Center-Norrtalje Study Group. Seeking care for low back pain in the general population: A two-year follow up study: Results
Author Affiliation

Pradeep Chopra, MD

Assistant Professor of Medicine

(Clinical)

Department of Medicine

Division of Biology and Medicine

Brown Medical School.

Assistant Professor of Anesthesiology

(Adjunct)

Boston University School of Medicine

Medical Director

Interventional Pain Management Center

Pawtucket, RI 02860

E-mail: painri@yahoo.com

Howard S. Smith, MD

Associate Professor of Anesthesiology

Academic Director of Pain Management

Albany Medical College

47 New Scotland Avenue

Albany, NY 12208

E-mail: smithh@mail.amc.edu

Timothy R. Deer, MD

Medical Director

The Center for Pain Relief

400 Court Street, Suite 304

Charleston WV 25301

E-mail: DocTDeer@aol.com

Richard C. Bowman, MD

The Center for Pain Relief

400 Court Street, Suite 304

Charleston WV 25301

E-Mail: jaimegbowman@yahoo.com

from the MUSIC-Norrtalje Study. Spine 2002; 27:2159-2165.

5. Ferguson SA, Marras WS, Gupta P. Longitudinal quantitative measures of the natural course of low back pain recovery. Spine 2000; 25:1950-1956.

6. Croft PR, Lewis $M$, Papageorgiou $A C$, Thomas E, Jayson MI, Macfarlane GJ, Silman AJ. Risk factors for neck pain: A longitudinal study in the general population. Pain 2001; 93:317-325.

7. Kuslich SD, Ulstrom CL, Michael CJ. The tissue origin of low back pain and sciatica: A report of pain response to tissue stimulation during operation on the lumbar spine using local anesthesia. Orthop Clin North Am 1991; 22:181-187.

8. Boden SD, Bholman HH (eds,). The Failed Spine. Etiology and therapy,. Lippincott Williams \&Wilkins, Philadelphia, 2003.

9. Alkalay RN, Kim DH, Urry DW, Xu J, Parker TM, Glazer PA. Prevention of postlaminectomy epidural fibrosis using bioelastic materials. Spine 2003; 28:1659-1665.
10. Ross JS, Roberston JT, Fredrickson RC, Petrie JL, Obuchowski N, Modic MT, deTribolet N. Association between peridural scar and recurrent radicular pain after lumbar discectomy: Magnetic resonance evaluation. Neurosurgery 1996; 38:855-861.

11. Hoyland JA, Fremont AJ, Jayson MI. Intervertebral foramen venous obstruction. A cause of periradicular fibrosis? Spine 1989; 14:558-568.

12. Fritsch EW, Heisel J, Rupp S. The failed back surgery syndrome. Reasons, intraoperative findings, and long-term results: $A$ report of 182 operative treatments. Spine 1996; 21:626-633.

13. North RB, Campbell JN, James CS, Conover-Walker MK, Wang $\mathrm{H}$, Piantadosi S, Rybock JD, Long DM. Failed back surgery syndrome: 5-year follow-up in 102 patients undergoing repeated operation. Neurosurgery 1991; 28:685-691.

14. Dullerud R, Graver V, Haakonsen M, Haaland AK, Loeb M, Magnaes B. Influence of fibrinolytic factors on scar formation after lumbar discectomy. A magnetic resonance imaging follow-up study with correlation performed 7 years after surgery. Spine 1998; 23:1464-1469.

15. Cervellini P, Curri D, Volpin L, Bernardi L, Pinna V, Benedetti A. Computed tomography of epidural fibrosis after discectomy. A comparison between symptomatic and asymptomatic patients. Neurosurgery 1988; 6:710-713.

16. Pawl RP. Arachnoiditis and epidural fibrosis: The relationship to chronic pain. Curr Rev Pain 1998; 2:93-99.

17. Songer M, Ghosh L, Spencer D. Effects of sodium hyaluronate on peridural fibrosis after lumbar laminectomy and discectomy. Spine 1990; 15:550-554.

18. Coskun E, Suzer T, Topuz O, Zencir M, Pakdemirli E, Tahta K. Relationships between epidural fibrosis, pain, disability, psychological factors after lumbar disc surgery. Eur Spine / 2000; 9:218-223.

19. LaRocca H, Macnab I. The laminectomy membrane: Studies in its evolution, characteristics, effects and prophylaxis in dogs. J Bone Joint Surg BR 1974; 56:545550.

20. McCarron RF, Wimpee MW, Hudkins PG, Laros GS. The inflammatory effects of nucleus of nucleus pulposus: A possible element in the pathogenesis of low back pain. Spine 1987; 12:760-764.

21. Cooper RG, Freemont AJ, Hoyland JA, Jenkins JP, West CG, Illingworth KJ, Jayson MI. Herniated intervertebral disc-associated periradicular fibrosis and vascular abnormalities occur without inflammatory cell infiltration. Spine 1995; 20:591-598.

22. Parke WW, Watanabe R. Adhesions of the ventral lumbar dura. Adjunct source of discogenic pain? Spine 1990; 15:300-303.

23. Olmarker K, Rydevik B. Pathophysiology of spinal nerve roots as related to sciatica and disc herniation. In Herkowitz HN, Garfin SR, Simeone FA (eds). Rothman-Sime- 
one Studies, The Spine. WB Saunders, Philadelphia, 1999, pp 159-172.

24. Rydevik BL. The effects of compression on the physiology of nerve roots. J Manipulative Physiol Ther 1992; 15:62-66.

25. Phillips FM, Cunningham B. Managing chronic pain of spinal origin after lumbar surgery. Spine 2002; 27:2547-2553.

26. Manchikanti L, Bakhit CE. Percutaneous lysis of epidural adhesions. Pain Physician 2000; 3:46-64.

27. Viesca C, Racz G, Day M. Spinal techniques in pain management: lysis of adhesions. Anesthesiol Clin North America 2003; 21:745-766.

28. Manchikanti L, Singh V. Epidural lysis of adhesions and myeloscopy. Curr Pain Headache Rep 2002; 6:427-435.

29. Manchikanti L, Saini B, Singh V. Spinal endoscopy and lysis of epidural adhesions in the management of chronic low back pain. Pain Physician 2001; 4:240-265.

30. Saberski L, Brull S. Spinal and epidural endoscopy: A historical review. Yale J Bio Med 1995; 68:7-15.

31. West S, King V, Carey T, Lohr K, McKoy $N$, Sutton S, Lux L. Systems to rate the strength of scientific evidence. Evidence Report/Technology Assessment No. 47 University of North Carolina: Agency for Healthcare Research and Quality. AHRQ Publication No. 02-E016; April 2002

32. van Tulder M, Assendelft W, Koes B, Bouter LM. Method guidelines for systematic reviews in the Cochrane Collaboration Back Review Group for Spinal Disorders. Spine 1997; 22:2323-2330.

33. Shekelle PG, Andersson G, Bombardier $C$, et al. A brief introduction to the critical reading of the clinical literature. Spine 1994;19(suppl):2028S-2031S.

34. Heavner JE, Racz GB, Raj P. Percutaneous epidural neuroplasty. Prospective evaluation of $0.9 \% \mathrm{NaCl}$ versus $10 \% \mathrm{NaCl}$ with or without hyaluronidase. Reg Anesth Pain Med 1999; 24:202-207.

35. Racz GB, Heavner JE, Raj PP. Percutaneous epidural neuroplasty. Prospective one-year follow up. Pain Digest 1999; 9: 97-102.

36. Manchikanti L, Rivera J, Pampati V, Damron KS, MCManus CD, Brandon DE, Wilson SR. One day lumbar epidural adhesiolysis and hypertonic saline neurolysis in treatment of chronic low back pain: A randomized double blind trial. Pain Physician. 2004; 7:177-186.

37. Manchikanti L, Pampati V, Fellows B, Rivera JJ, Beyer CD, Damron KS. Role of one day epidural adhesiolysis in management of chronic low back pain: A randomized clinical trial. Pain Physician 2001; 4:153166.

38. Manchikanti L, Pakanati R, Bakhit CE, Pampati V. Role of adhesiolysis and hypertonic saline neurolysis in management of low back pain. Evaluation of modification of Racz protocol. Pain Digest 1999; 9:9196.
39. Manchikanti L, Pampati V, Bakhit CE, Pakanati RR. Non-endoscopic and endoscopic adhesiolysis in post lumbar laminectomy syndrome. A one-year outcome study and cost effective analysis. Pain Physician 1999; 2:52-58.

40. Manchikanti L, Pampati V, Rivera J, Fellows B, Beyer CD, Damron KS, Cash KA. Effectiveness of percutaneous adhesiolysis and hypertonic saline neurolysis in refractory spinal stenosis. Pain Physician 2001; 4:366-373.

41. Racz GB, Holubec JT. Lysis of adhesions in the epidural space. In Racz GB (ed). Techniques of Neurolysis. Kluwer Academic press, Boston, 1989, pp 57-72.

42. Hammer M, Doleys D, Chung O. Transforaminal ventral epidural adhesiolysis. Pain Physician 2001; 4: 273-279.

43. Devulder J, Bogaert L, Castille F, Moerman A, Rolly G. Relevance of epidurography and epidural adhesiolysis in chronic failed back surgery patients. Clin J Pain 1995; 11: 147-150.

44. Arthur J, Racz GB, Heinrich R, Diede JH, McCann M, Wilson E, Heavner J C., Noe C. Epidural space. Identification of filling defects in lysis of adhesions in the treatment of chronic painful conditions. In: $A b$ stracts, 7th World Congress of Pain. Paris, IASP Publications, 1993, pp 557.

45. Manchikanti L, Rivera JJ, Pampati V, Damron KS, Beyer CD, Brandon DE, Wilson SR. Spinal endoscopic adhesiolysis in the management of chronic low back pain: $A$ preliminary report of a randomized, double-blind trial. Pain Physician 2003; 6: 259-268.

46. Manchikanti L, Boswell MV, Rivera JJ, Pampati V, Damron KS, McManus CD, Brandon $\mathrm{DE}$, Wilson SR. A randomized, controlled trial of spinal endoscopic adhesiolysis in chronic refractory low back and lower extremity pain. 2005; in press.

47. Geurts JW, Kallewaard JW, Richardson J, Groen. Targeted methylprednisolone acetate/hyaluronidase/clonidine injection after diagnostic epiduroscopy for chronic sciatica: a prospective, 1-year follow-up study. Reg Anesth Pain Med 2002; 27:343-352.

48. Igarashi T, Hirabayashi Y, Seo N, Saitoh K, Fukuda H, Suzuki H. Lysis of adhesions and epidural injection of steroid/local anesthetic during epiduroscopy potentially alleviate low back and leg pain in elderly patients with lumbar spine stenosis. $\mathrm{Br} J$ Anaesth 2004; 93:181-187.

49. Richardson J, McGurgan P, Cheema S, Prasad R, Gupta S. Spinal endoscopy in chronic low back pain with radiculopathy: A prospective case series. Anaesthesia 2001; 56:454-460.

50. Manchikanti L. The value and safety of epidural endoscopic adhesiolysis. Am J Anesthesiol 2000; 275-278.

51. Saberski L. A retrospective analysis of spinal canal endoscopy and laminectomy outcomes data. Pain Physician 2000; 3:
193-196.

52. Lewandowski EM. The efficacy of solutions used in caudal neuroplasty. Pain Digest 1997; 7:323-330.

53. Houten JK, Errico TJ. Paraplegia after lumbosacral nerve root block: Report of three cases. Spine J 2002; 2:70-75.

54. Bromage RP, Benumof JL. Paraplegia following intracord injection during attempted epidural anesthesia under general anesthesia. Reg Anesth Pain Med 1998; 23: 104-107.

55. MacLean CA, Bachman DT. Documented arterial gas embolism after spinal epidural injection. Ann Emerg Med 2001; 38:592595 .

56. Mateo E, Lopez-Alarcon MD, Moliner S, Calabuig E, Vivo M, De Andres J, Grau F. Epidural and subarachnoid pneumocephalus after epidural technique. Eur J Anesthesiol 1999; 16:413-417.

57. Katz JA, Lukin R, Bridenbaugh PO, Gunzenhauser L. Subdural intracranial air: An unusual cause of headache after epidural steroid injection. Anesthesiology 1991; 74: 615.

58. Benzon HT, Wong HY, Siddiqui T, Ondra S. Caution in performing epidural injections in patients on several antiplatelet drugs. Anesthesiology 1999; 91:1558-1559.

59. Mamourian AC, Dickman CA, Drayer BP, Sonntag VK. Spinal epidural abscess: Three cases following spinal epidural injection demonstrated with magnetic resonance imaging. Anesthesiology 1993; 78: 204-207.

6o. Knight JW, Cordingley JJ, Palazzo MG. Epidural abscess following epidural steroid and local anesthetic injection. Anaesthesia 1997; 52:576-578.

61. Vijayan N, Dreyfus PM. Chemical epidural abscess: Case report. J Neurol Neurosurg Psychiatry 1971; 34:297-299.

62. Kaul S, Meena AK, Sundaram C, Reddy JM, Naik RT, Murthy JM. Spinal extradural abscess following local steroid injection. Neurol India 2000; 48:181-183.

63. Chan ST, Leung S. Spinal epidural abscess following steroid injection for sciatica: Case report. Spine 1989; 14:106-108.

64. Goucke CR, Graziotti P. Extradural abscess following local anaesthetic and steroid injection for chronic low back pain. Brit J Anesth 1990; 65:427-429.

65. Yamaguchi M, Kawakubo A, Ide R, Hara K, Sumikawa K. Epidural abscess associated with epidural block in a patient with immunosuppressive disease. Jpn J Anesthesiol 1999; 48:506-508.

66. Sabel M, Felsberg J, Neuen-Jacob E, Lichota A, Schnitzler A, Herdmann J. Enlargement of a chronic aseptic lumbar epidural abscess by intraspinal injections-a rare cause of progressive paraparesis. Zentralbl Neurochir 2000; 61:111-114.

67. Gutknecht DR. Chemical meningitis following epidural injections of corticosteroids (Letter). Am J Med 1987; 82:570. 
68. Williamson JA. Inadvertent spinal subdural injection during attempted spinal epidural steroid therapy. Anaesth Intens Care 1990; 18:406-408.

69. Lubenow T, Keh-Wong E, Kristof K, Ivankovich O, Ivankovich AD. Inadvertent subdural injection: A complication of an epidural block. Anesth Analg 1988; 67:175-179.

70. Dreskin S, Bajwa ZH, Lehmann L et al. Polymyoclonus resulting from possible accidental subdural injection of local anesthetic. Anesth Analg 1997; 84:692-693.

71. Kim RC, Porter RW, Choi BH, Kim SW. Myelopathy after intrathecal administration of hypertonic saline. Neurosurgery 1988; 22:942-944.

72. Aldrete JA, Zapata JC, Ghaly R. Arachnoiditis following epidural adhesiolysis with hypertonic saline report of two cases. Pain Digest 1996; 6:368-370.

73. Hitchcock ER, Prandini MN. Hypertonic saline in management of intractable pain. Lancet 1973; 1:310-312.

74. Lucas JT, Ducker TB, Perot PL. Adverse re actions to intrathecal saline injections for control of pain. J Neurosurg 1975; 42:57561.

75. Dagi TF. Comments on myelopathy after the intrathecal administration of hypertonic saline. Neurosurgery 1988; 22:944945.

76. Lundy JS, Essex HE, Kernohan JW. Experiments with anesthetics. IV. Lesions produced in the spinal cord of dogs by a dose of procaine hydrochloride sufficient to cause permanent and fatal paralysis. JAMA 1936; 101: 1546-1550.

77. Gentili ME, Samii K. Accidental epidural injection of hypertonic sodium chloride solution. Ann Fr Anesth Reanim 1991; 10: 401-403.

78. Manchikanti L, Bakhit CE. Removal of torn Racz catheter from lumbar epidural space. Reg Anesth 1997; 22:579-581.

79. Tabandeh H. Intraocular hemorrhages associated with endoscopic spinal surgery. Am J Ophthalmol 2000; 129:688-69o.

8o. Hammer M. Safety of spinal endoscopy is contingent on basic image interpretation. Letter to the editor. Reg Anesth Pain Med
2002; 27:621.

81. Kusher FH, Olson JC. Retinal hemorrhage as a consequence of epidural steroid injection. Arch Opthalmol 1995; 113:309313.

82. Purdy EP, Gurjit SA. Vision loss after lumbar epidural steroid injection. Anesth Analg 1998; 86:119-122.

83. Kao LY. Bilateral serous retinal detachment resembling central serious chorioretinopathy following epidural steroid injection. Retina 1998; 18:479-481.

84. Sandberg DI, Lavyne MH. Symptomatic spinal epidural lipomatosis after local epidural corticosteroid injections: Case report. Neurosurgery 1999; 45:162-165.

85. Trattner A, Hodak E, David M, Neeman A, Sandbank M. Kaposi's sarcoma with visceral involvement after intraarticular and epidural injections of corticosteroids. J Am Acad Dermatol 1993; 29:890-894.

86. Knight CL, Burnell JC. Systemic side effects of extradural steroids. Anaesthesia 1980; 35:593-594.

87. Jacobs S, Pullan PT, Potter JM, Shenfield GM. Adrenal suppression following extradural steroids. Anaesthesia 1983; 38:953956.

88. Boonen S, Van Distel G, Westhovens R, Dequeker J. Steroid myopathy induced by epidural triamcinolone injection. Brit J Rheumatol 1995; 34:385-386.

89. Maillefert JF, Aho S, Huguenin MC, Chatard C, Peere T, Marquignon MF, Lucas B, Tavernier C. Systemic effects of epidural dexamethasone injections. Revue du Rhumatisme 1995; 62:429-432.

90. Ward A, Watson J, Wood P, Dunne C, Kerr D. Glucocorticoid epidural for sciatica: Metabolic and endocrine sequelae. Rheumatology 2002; 41:68-71.

91. Manchikanti L, Pampati V, Beyer CD, Damron KS, Cash KA, Moss TL. The effect of neuraxial steroids on weight and bone mass density: A prospective evaluation. Pain Physician 2000; 3:357-366.

92. Milhaud D, Heroum C, Charif M, Saulnier P, Pages M, Blard JM. Dural puncture and corticotherapy as risks factors for cerebral venous sinus thrombosis. Eur J Neruol
2000; 7:123-124.

93. Delaney TJ, Rowlingson JC, Carron H, Butler A. Epidural steroid effects on nerves and meninges. Anesth Analg 1980; 58: 610-614.

94. Mackinnon SE, Hudson AR, Gentili F, Kline DG, Hunter D. Peripheral nerve injection injury with steroid agents. Plast Reconstr Surg 1982; 69:482-489.

95. Chino N, Awad EA, Kottke FJ. Pathology of propylene glycol administered by perineural and intramuscular injection in rats. Arch Phys Med Rehab 1974; 55:33-38.

96. Benzon HT, Gissen AJ, Strichartz GR, Avram MJ, Covino BG. The effect of polyethylene glycol on mammalian nerve impulses. Anesth Analg 1987; 66:553-559.

97. Abram SE, Marsala M, Yaksh TL. Analgesic and neurotoxic effects of intrathecal corticosteroids in rats. Anesthesiology 1994; 81:1198-1205.

98. Latham JM, Fraser RD, Moore RJ, Blumbergs PC, Bogduk N. The pathologic effects of intrathecal betamethasone. Spine 1997; 22:1558-1562.

99. Robustelli della Cuna FS, Mella M, Magistrali G, Ricci M, Losurdo A, Goglio AM. Stability and compatibility of methylprednis olone acetate and ropivacaine hydrochloride in polypropylene syringes for epidural administration. Am J Health Syst Pharm 2001; 58:1753-1756.

100. Slucky AV, Sacks MS, Pallares VS, Malinin TI, Eismont FJ. Effects of epidural steroids on lumbar dura material properties. J Spin Disord 1999; 12:331-340.

101. Manchikanti L. Role of neuraxial steroids in interventional pain management. Pain Physician 2002; 5:182-199.

102. Bogduk N, McGuirk B. Monotherapy. In Bogduk N, McGuirk B (eds). Medical Management of Acute and Chronic Low Back pain. An Evidence-Based Approach: Pain Research and Clinical Management, Vol. 13, Elsevier Science BV, Amsterdam, 2002: 143-161.

103. Fibuch EE. Percutaneous epidural neuroplasty: Cutting edge or potentially harmful pain management? Reg Anesth Pain Med 1999; 24:198-201. 
